\title{
Prospective evaluation of hepatitis B, C and HIV infections as possible sequelae of antineoplastic treatment in paediatric sarcoma patients: A report from the Late Effects Surveillance System
}

\author{
MARIOS PAULIDES $^{1}$, WOLFGANG STÖHR ${ }^{1}$, STEFAN BIELACK ${ }^{2,3}$, HERIBERT JÜRGENS ${ }^{4}$, \\ EWA KOSCIELNIAK ${ }^{5}$, THOMAS KLINGEBIEL ${ }^{6}$, ROBERT ZIMMERMANN ${ }^{7}$, \\ DANIEL STACHEL ${ }^{1}$, THORSTEN LANGER ${ }^{1}$ and JÖRN-DIRK BECK ${ }^{1}$ \\ ${ }^{1}$ LESS Centre, University Hospital for Children and Adolescents, Department of Paediatric Oncology and \\ Immunology, Erlangen; ${ }^{2}$ Cooperative Osteosarcoma Study Group, University Children's Hospital Muenster, \\ Department of Paediatric Haematology and Oncology, Muenster; ${ }^{3}$ Olgahospital, Paediatrics 5 (Oncology, \\ Haematology, Immunology), Stuttgart; ${ }^{4}$ Ewing's Sarcoma Trial Centre, University Children's Hospital Muenster, \\ Department of Paediatric Haematology and Oncology, Muenster; ${ }^{5}$ Cooperative Soft Tissue Sarcoma Study, \\ Olgahospital, Paediatrics 5 (Oncology, Haematology, Immunology), Stuttgart; ${ }^{6}$ Cooperative Soft Tissue Sarcoma Study, \\ Klinik für Kinderheilkunde III (Paediatric Haematology, Oncology and Haemostaseology), \\ Klinikum der Johann-Wolfgang-Goethe-Universität, Frankfurt; ${ }^{7}$ Department of Transfusion Medicine and \\ Haemostaseology, Friedrich-Alexander University Erlangen-Nürnberg, Erlangen, Germany
}

Received October 11, 2005; Accepted November 28, 2005

\begin{abstract}
Cancer therapy and supportive measures entail the risk of infection with hepatitis $\mathrm{B}(\mathrm{HBV})$, hepatitis $\mathrm{C}(\mathrm{HCV})$ or human immunodeficiency virus (HIV). The objective of this analysis was to establish the incidence of infections with these viruses during antineoplastic treatment in our paediatric sarcoma patients, who are being followed-up within the Late Effects Surveillance System (LESS), which prospectively registers sequelae of therapy for Ewing's-, soft tissue- and osteosarcoma in patients treated in Germany, Austria and Switzerland within the trials EICESS-92/EURO-E.W.I.N.G.99, CWS-96/CWS-2002P and COSS-96. We studied 264 eligible relapse-free paediatric patients [median age at diagnosis 14.3 (IQR 11.1-16.4) years], treated from January 7, 1998 until April 24, 2004. According to the LESS protocol, serological examinations for HBV, HCV and HIV were scheduled 4 weeks and 6 months after cessation of antineoplastic treatment. The median follow-up was 20.6 (IQR 12.4-26) months. None of the
\end{abstract}

Correspondence to: Professor J.D. Beck, Department of Paediatric Immunology and Oncology, University Hospital for Children and Adolescents, Loschgestrasse 15, 91054 Erlangen, Germany E-mail: less@kinder.imed.uni-erlangen.de

Key words: human immunodeficiency virus, hepatitis, transfusion, cancer, late effects patients was reported to have acquired $\mathrm{HBV}, \mathrm{HCV}$ or HIV during antineoplastic treatment. Blood donor screening and prophylactic measures employed in Germany, Austria and Switzerland to prevent infections of cancer patients with $\mathrm{HBV}, \mathrm{HCV}$ and HIV seem to be very effective, having fully prevented new infections in this large cohort of paediatric sarcoma patients.

\section{Introduction}

Patients receiving cancer therapy are at risk of infection with a multitude of agents. These include infections with hepatitis B (HBV), hepatitis C (HCV) or human immunodeficiency virus (HIV). In cancer patients, infection with these viruses is mainly iatrogenic in non-endemic areas, for example through transfusion of contaminated blood products (1), immune globulins (2), or contaminated equipment (3). Fulminant hepatitis $(1,4)$, chronic hepatitis $(1,5)$ as well as chronic carrier status (4-7), cirrhosis $(6,8,9)$, hepatic failure $(6,8)$ and hepatocellular carcinoma (6) have been described in HBVand/or HCV- infected cancer patients. However, evaluations of these virus infections are rare for large homogeneous cohorts of paediatric cancer patients, especially in children that have risk factors for infection other than transfusions, such as major surgery (10).

The aim of this analysis was to determine the cumulative incidence of infections with HBV, HCV and HIV during antineoplastic therapy within a homogeneous population of relapse-free, prospectively examined, paediatric sarcoma patients. 
Table I. Characteristics of the patient groups with and without reported results for HBV, HCV and HIV examinations. ${ }^{a}$

\begin{tabular}{|c|c|c|c|}
\hline & $\begin{array}{l}\text { Patients with at least one reported result } \\
\qquad \mathrm{N}=264\end{array}$ & $\begin{array}{l}\text { Patients with no reported results } \\
\qquad \mathrm{N}=222\end{array}$ & p-value \\
\hline \multicolumn{4}{|l|}{ Gender } \\
\hline Male & $148(56 \%)$ & $110(49.5 \%)$ & \\
\hline Female & $116(44 \%)$ & $112(50.5 \%)$ & 0.17 \\
\hline \multicolumn{4}{|l|}{ Sarcoma } \\
\hline Ewing's & $81(30.7 \%)$ & $45(20.3 \%)$ & \\
\hline Soft tissue & $83(31.4 \%)$ & $64(28.8 \%)$ & \\
\hline Osteosarcoma & $100(37.9 \%)$ & $113(50.9 \%)$ & 0.007 \\
\hline $\begin{array}{l}\text { Median age at } \\
\text { diagnosis in years }\end{array}$ & $\begin{array}{c}14.3 \\
(\text { IQR } 11.1-16.4)\end{array}$ & $\begin{array}{c}14.4 \\
(\mathrm{IQR} 11.9-16.6)\end{array}$ & 0.26 \\
\hline $\begin{array}{l}\text { Median follow-up } \\
\text { in months }\end{array}$ & $\begin{array}{c}20.6 \\
\text { (IQR 12.4-26) }\end{array}$ & $\begin{array}{c}38.7 \\
(I Q R 24.2-51.1)\end{array}$ & $<0.001$ \\
\hline \multicolumn{4}{|l|}{ Results } \\
\hline $\begin{array}{l}\text { Negative } \\
\text { No report } \\
\text { Not done }\end{array}$ & $\begin{array}{r}199 \\
52 \\
13\end{array}$ & $\begin{array}{r}- \\
204 \\
18\end{array}$ & \\
\hline \multicolumn{4}{|l|}{ E1 } \\
\hline Negative & 244 & - & \\
\hline No report & 13 & 203 & \\
\hline Not done & 7 & 19 & \\
\hline
\end{tabular}

${ }^{a} \mathrm{E} 0$, examination at 4 weeks after end of therapy. E1, examination at 6 months after end of therapy. All patients in both groups presented for both these follow-up examinations. IQR, interquartile range.

\section{Materials and methods}

The Late Effects Surveillance System (LESS) is a multinational multicentre study that prospectively registers sequelae of cancer therapy. Herein we report on patients with Ewing's-, soft tissue- and osteosarcoma treated in Germany, Austria and Switzerland (11-14) within the trials EICESS-92/ EUROE.W.I.N.G.-99, CWS-96/CWS-2002P, COSS-96. All studies have been approved by an ethics committee and a written informed consent was available for every patient. We have previously reported on treatment toxicities in our study population (15).

According to the LESS protocol, serological examinations for HBV, HCV and HIV are scheduled 4 weeks and 6 months after cessation of antineoplastic treatment and are carried out at the hospital or general practitioner conducting follow-up. No specific examinations are prescribed. Only positivity or negativity for the respective viruses is reported to the LESS centre. Basic hepatic examinations include clinical examination (scheduled at least every 3 months in the first and second year, with lower frequency in subsequent years) and at least yearly examinations of transaminase and bilirubin concentrations in the patient serum $(11,12)$.

Since January 1, 1998, 1780 patients have been included in the LESS-study. Follow-up within the LESS-study ceases when relapse or a second malignancy occur. For this analysis, we excluded patients $>21$ years of age, patients with stem cell transplantation, patients who had no reported follow-up at both aforementioned examination points and those who had been identified as being infected prior to the initiation of antineoplastic treatment. Thus, 486 patients were eligible.

Statistical analysis. Bivariate analyses of categorial variables were made by Fisher's exact test, and continuous variables were analysed using the Mann-Whitney U test. All analyses were performed using SAS (version 8.2, SAS Institute Inc., Cary, $\mathrm{NC}$ ). Statistical significance was defined as two-tailed p-value of $\leq 0.05$.

\section{Results}

There were 486 eligible relapse-free paediatric patients who had presented for follow-up at both examinations at 4 weeks and 6 months after the end of antineoplastic therapy. However, in $222(46 \%)$ of these patients no results for virus tests were reported or the appropriate tests were not done, which left 264 patients with at least one reported result (Table I). Patients with reported results and those without did not differ in gender and age at diagnosis, but in tumour type (less results in osteosarcoma patients than in Ewing's sarcoma patients) 
Table II. Characteristics of patients with viral infections diagnosed before antineoplastic therapy .

\begin{tabular}{lccccc}
\hline Patient & Gender & Malignancy & Age at cancer diagnosis in years & Follow-up in months & Virus infection(s) \\
\hline 1 & Male & Osteosarcoma & 19 & 55 & Hepatitis B \\
Hepatitis C & Hepatitis B \\
2 & Male & Osteosarcoma & 17 & 64 & Hepatitis C \\
3 & Female & Ewing's sarcoma & 10 & 56 & Hepatitis G \\
4 & & & 10 & 28 & Hepatitis B \\
\hline
\end{tabular}

and in length of follow-up (longer in patients without reported virus examination results). None of the 264 patients were reported to have acquired HBV, HCV or HIV during antineoplastic treatment.

Hepatic status was reported in 261 of the 264 patients with at least one reported virus serology status. There were no reports of sustained high liver function tests or other indications for hepatitis. There were, however, four patients who had been excluded from analysis for positive examination results already diagnosed before cancer therapy. Their details are given in Table II.

\section{Discussion}

No examined patient treated within our sarcoma trials from January 7, 1998 until April 24, 2004 was reported as having been infected with HBV, HCV or HIV under antineoplastic treatment. Our results indicate that blood product screening (16-18) and prophylactic measures (1) employed in Austria, Germany and Switzerland seem to be sufficient to protect paediatric cancer patients from infection with $\mathrm{HBV}, \mathrm{HCV}$ or HIV.

It has been recently stated that transfusion of blood products has become a very safe therapeutic modality $(2,3,18,19)$ and it seems that invasive procedures, which have been previously described as risk factors for infection with aforementioned viruses $(7,10)$, are also safe when managed properly (10).

The safety of blood products is supported by reports showing very low risks of infection with HBV, HCV and HIV through blood transfusion in industrial countries in the last years, with estimated residual risks per million donations for HBV, HCV and HIV being 1.66-13.88, 0.1-6.69 and 0.141.95 respectively $(17,20-24)$.

Studies on paediatric cancer patients transfused before routine HCV testing of blood products became available, report highly variable cumulative incidences of $\leq 72 \%$ for $\mathrm{HBV}$ and/or HCV, depending on country and endemic environment $(6,7,9,25,26)$. In endemic environments, even after the introduction of routine $\mathrm{HCV}$ testing of blood products, there have been reported rates of $12.9-19.2 \%$ seropositivity for HBV and/or HCV in paediatric cancer patients $(4,10)$.

An early German study in adults undergoing surgery for various diseases, including cancers, reported newly acquired hepatitis in $6.7 \%$ of transfused patients and in $0.65 \%$ of nontransfused patients $(27,28)$. In Germany, anti-hepatitis B serum antigen (HBsAg) testing was introduced widely in the early 70 s and became compulsory in 1977, while anti-hepatitis B core antigen (HBc) testing commenced around 1975, though remaining elective until today, just like HBV nucleic acid testing (NAT) has. Testing for anti-HCV was widely introduced in 1990 and HCV-NAT is compulsory since April 1, 1999 (October 1, 1999 for fresh frozen plasma). Regarding HIV, anti-HIV testing is compulsory since October 1, 1985 and HIV-NAT since April 30, 2004.

Thus, our patients were treated in an era of standardised serological donor blood screening, in contrast to those reported upon in aforementioned early study in Germany, since at their hospital there was only anti-HBsAg screening available at that time, having been newly introduced in 1970 .

As the LESS-study has been conceived as part of a vertical cost effective network, sophisticated examinations such as HBV-NAT are not mandatory so as to enable all participating follow-up institutions, from university hospitals to general practitioners, to conduct the follow-up using widely available means. We included only those patients into this analysis, who had presented for both follow-up examinations at which serological virus tests were scheduled. Of the eligible patients, $46 \%$ had no reported result or no virus test at either of the two scheduled examinations. For further investigation, we analysed the years in which patients of the groups with and without reported results were diagnosed and found that there is a significant difference between patients in earlier years of the study and patients in recent years, with more recently diagnosed patients having more frequently reported results for virus examinations. This is probably due to a change of methodology that was instituted in the LESS-study. Up until 2001 , only positive results had to be reported. After 2001, a new form was introduced for reporting any result. This could also explain the difference in length of follow-up. Those patients without a reported virus test result are likely to have been diagnosed in the early phase, thus having longer follow-up.

There was also a statistically significant difference between the two groups regarding tumour type. We cannot really explain this difference, as the late effects follow-up recommendations for all these sarcomas are very similar. We have discussed the methodological problems of data return and data completeness in the LESS-study previously in detail (14).

To complement our results, we also reviewed reported hepatic status in this study population. There were no reports 
of sustained high transaminase or bilirubin serum levels or other indicators for hepatitis. Nevertheless, there remains a possibility that infections were not detected or were underreported, causing underestimation of cumulative incidences.

A limitation of our study is that no detailed data on transfused blood products were available. However, patients that are treated in centres farther away from their residence often receive supportive therapy, such as transfusions, in local hospitals and it has also been previously reported that clinical patient records often do not fully correspond with transfusion service records $(29,30)$. Since most of our patients received major surgery and all of them had very intensive polychemotherapy, it is safe to assume that most of them will have had at least one transfusion (7).

These results on cumulative incidence of $\mathrm{HBV}, \mathrm{HCV}$ and HIV infections acquired under sarcoma therapy including polychemotherapy suggest that in industrialised countries attention must shift to combating other types of transfusiontransmitted infections and other consequences of transfusion, such as immunologic reactions and, of course, preventable human error (16,19,31-36).

\section{Acknowledgements}

This study was supported by the Madeleine-Schickedanz KinderKrebs Stiftung. We wish to thank G. Melzer for data entry, the GPOH trial centers for Ewing's sarcoma (S. Ahrens and R. Kloss), osteosarcoma (M. Kevric), and soft tissue sarcoma (E. Hallmen and I. Veit), and all the staff in the cooperating hospitals as well as the general practitioners for the transfer of patient data.

\section{References}

1. Gigliotti AR, Fioredda F and Giacchino R: Hepatitis B and $\mathrm{C}$ infection in children undergoing chemotherapy or bone marrow transplantation. J Pediatr Hematol Oncol 25: 184-192, 2003.

2. Ceccherini-Nelli L, Filipponi F, Mosca F and Campa M: The risk of contracting an infectious disease from blood transfusion. Transplant Proc 36: 680-682, 2004.

3. Regan FA, Hewitt P, Barbara JA and Contreras M: Prospective investigation of transfusion transmitted infection in recipients of over 20,000 units of blood. TTI Study Group. BMJ 320: 403-406, 2000 .

4. Sevinir B, Meral A, Gunay U, Ozkan T, Ozuysal S and Sinirtas M: Increased risk of chronic hepatitis in children with cancer. Med Pediatr Oncol 40: 104-110, 2003.

5. Fioredda F, Gigliotti AR, Haupt R, Calevo MG, Giudice CL, Bocciardo L and Giacchino R: HCV infection in very-long-term survivors after cancer chemotherapy and bone marrow transplantation: A single-center experience. J Pediatr Hematol Oncol 27: 481-485, 2005.

6. Strickland DK, Riely CA, Patrick CC, Jones-Wallace D, Boyett JM, Waters B, Fleckenstein JF, Dean PJ, Davila R, Caver TE and Hudson MM: Hepatitis C infection among survivors of childhood cancer. Blood 95: 3065-3070, 2000.

7. Kebudi R, Ayan I, Yilmaz G, Akici F, Gorgun O and Badur S: Seroprevalence of hepatitis $B$, hepatitis $C$, and human immunodeficiency virus infections in children with cancer at diagnosis and following therapy in Turkey. Med Pediatr Oncol 34: 102-105, 2000 .

8. Castellino S, Lensing S, Riely C, Rai SN, Davila R, Hayden RT, Fleckenstein J, Levstik M, Taylor S, Dean PJ, Kippenbrock S, Pope J, Carr J, Strickland DK and Hudson MM: The epidemiology of chronic hepatitis $\mathrm{C}$ infection in survivors of childhood cancer: an update of the St. Jude Children's Research Hospital hepatitis C seropositive cohort. Blood 103: 2460-2466, 2004.
9. Leung W, Hudson MM, Strickland DK, Phipps S, Srivastava DK, Ribeiro RC, Rubnitz JE, Sandlund JT, Kun LE, Bowman LC, Razzouk BI, Mathew P, Shearer P, Evans WE and Pui CH: Late effects of treatment in survivors of childhood acute myeloid leukemia. J Clin Oncol 18: 3273-3279, 2000.

10. Koltan S, Styczynski J, Wysocki M, Koltan A, Kurylak A and Debski R: Decrease of dual hepatitis $B$ and $C$ virus infections in children with cancer: changes in risk factors over 30 years. Haematologica 89: 251-252, 2004.

11. Beck JD, Winkler K, Niethammer D, Brandis M, Hertzberg H, Von der HK, Greil J, Uberall MA, Lamprecht-Dinnesen A and Rossi R: After-care of children and young adults surviving cancer. Initial recommendations by the late sequelae study group. Klin Padiatr 207: 186-192, 1995.

12. Langer T, Henze $G$ and Beck J: Basic methods and the developing structures of a late effects surveillance system (LESS) in the long-term follow-up of pediatric cancer patients in Germany. Med Pediatr Oncol 34: 348-351, 2000.

13. Langer T, Stohr W, Bielack S, Paulussen M, Treuner J and Beck JD: Late effects surveillance system for sarcoma patients. Pediatr Blood Cancer 42: 373-379, 2004.

14. Langer T, Stohr W, Paulides M, Kremers A, Dorr HG, Gobel U and Beck JD: Prospective multicenter registration of major late sequelae in sarcoma patients using the Late Effects Surveillance System (LESS). Klin Padiatr 217: 176-181, 2005.

15. Stohr W, Langer T, Kremers A, Brecht I, Treuner J, Dinnesen A and Beck JD: Hearing function in soft tissue sarcoma patients after treatment with carboplatin: a report from the Late Effects Surveillance System. Oncol Rep 12: 767-771, 2004.

16. Allain JP: Transfusion risks of yesterday and of today. Transfus Clin Biol 10: 1-5, 2003.

17. Offergeld R, Ritter S, Faensen D and Hamouda O: Report of the Robert Koch Institute according to Article 22 of the Transfusion Act for the years 2001 and 2002. Bundesgesundheitsblatt Gesundheitsforschung Gesundheitsschutz 47: 1216-1229, 2004.

18. Stark K, Werner E, Seeger E, Offergeld R, Altmann D and Kramer MH: Infections with HIV, HBV, and HCV among blood donors in Germany 1998 and 1999. Infus Ther Transfus Med 29: 305-307, 2002.

19. Dellinger EP and Anaya DA: Infectious and immunologic consequences of blood transfusion. Crit Care 8 (Suppl 2): S18S23, 2004.

20. Soldan K, Barbara JA, Ramsay ME and Hall AJ: Estimation of the risk of hepatitis $B$ virus, hepatitis $C$ virus and human immunodeficiency virus infectious donations entering the blood supply in England, 1993-2001. Vox Sang 84: 274-286, 2003.

21. Soldan K, Davison K and Dow B: Estimates of the frequency of $\mathrm{HBV}, \mathrm{HCV}$, and HIV infectious donations entering the blood supply in the United Kingdom, 1996 to 2003. Euro Surveill 10: 17-19, 2005.

22. Pillonel $\mathbf{J}$ and Laperche $\mathrm{S}$ : Trends in risk of transfusiontransmitted viral infections (HIV, HCV, HBV) in France between 1992 and 2003 and impact of nucleic acid testing (NAT). Euro Surveill 10: 5-8, 2005.

23. Chiavetta JA, Escobar M, Newman A, He Y, Driezen P, Deeks S, Hone DE, O'Brien SF and Sher G: Incidence and estimated rates of residual risk for HIV, hepatitis $\mathrm{C}$, hepatitis B and human T-cell lymphotropic viruses in blood donors in Canada, 1990-2000. CMAJ 169: 767-773, 2003.

24. Alvarez do Barrio M, Gonzalez Diez R, Hernandez Sanchez J and Oyonarte Gomez S: Residual risk of transfusion-transmitted viral infections in Spain, 1997-2002, and impact of nucleic acid testing. Euro Surveill 10: 20-22, 2005.

25. Arora B, Joshi YK, Salhan RN, Arya LS and Prakash S: Transfusion-associated hepatitis in children with hematologic malignancies in Northern India. Med Pediatr Oncol 41: 166-168, 2003.

26. Hoshiyama A, Kimura A, Fujisawa T, Kage M and Kato H: Clinical and histologic features of chronic hepatitis $\mathrm{C}$ virus infection after blood transfusion in Japanese children. Pediatrics 105: 62-65, 2000.

27. Schricker KT and Ehler R: Transfusion hepatitis in various operations (I). Med Welt 24: 999-1003, 1971.

28. Schricker KT and Ehler R: Transfusion hepatitis in various surgical operations (II). Med Welt 26: 1080-1083, 1971.

29. Tynell E, Norda R, Montgomery SM and Bjorkman A: Diagnosis and procedure-specific survival among transfusion of recipients in 1993 and 2000, Orebro County, Sweden. Vox Sang 88: 181-188, 2005. 
30. Use of blood products for elective surgery in 43 European hospitals. The Sanguis Study Group. Transfus Med 4: 251-268, 1994.

31. Reesink HW: European strategies against the parasite transfusion risk. Transfus Clin Biol 12: 1-4, 2005.

32. Perrotta PL and Snyder EL: Non-infectious complications of transfusion therapy. Blood Rev 15: 69-83, 2001.

33. Wagner SJ: Transfusion-transmitted bacterial infection: risks, sources and interventions. Vox Sang 86: 157-163, 2004.
34. Strong DM and Katz L: Blood-bank testing for infectious diseases: how safe is blood transfusion? Trends Mol Med 8: 355-358, 2002.

35. Sanchez R and Toy P: Transfusion related acute lung injury: a pediatric perspective. Pediatr Blood Cancer 45: 248-255, 2005.

36. Spiess BD: Risks of transfusion: outcome focus. Transfusion 44 : S4-S14, 2004. 